\title{
Microbiological attributes of a soil under history of swine wastewater application
}

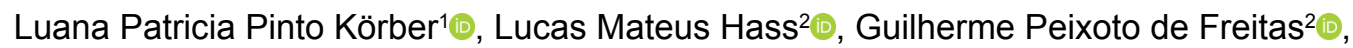

Késia Damaris de Azevedo Frigo ${ }^{1} \oplus$, Marco Antônio Bacellar Barreiros ${ }^{2} \oplus$,

Luciana Grange ${ }^{2}$, Elisandro Pires Frigo ${ }^{2}(\mathbb{A}$

\footnotetext{
1 Universidade Estadual do Oeste do Paraná, Cascavel, PR, Brasil. E-mail: luana.kozak@gmail.com; kesia.damaris@gmail.com

${ }^{2}$ Universidade Federal do Paraná, Palotina, PR, Brasil. E-mail: lucasmateushass@gmail.com; guilhermefreitasufpr@gmail.com; marcob_07@yahoo.com.br; lucianagrange@gmail.com; epfrigo@gmail.com
}

ABSTRACT: This research sought to study the effect of applying swine wastewater (SW) on the microbiological attributes of a clayey soil cultivated with physic nut (Jatropha curcas L.). This experimental area was subjected to SW applications for 3 years, followed by fallow for other 2 years. In December 2017, soil collections were carried out and the experiment conducted in randomized complete blocks (RCB) with six treatments and three replicates, namely T1: 0 (control), T2: 40, T3: 80, T4: 120, T5: 160 and T6: $200 \mathrm{~m}^{3} \mathrm{ha}^{-1}$. The evaluated attributes were the following: CFU, diversity, MBC, SBR, qCO and FDA. Values of the CFU means demonstrated an increase in the bacterial population density and the diversity pointed to the favoring of bacterial morphotypes already present in the soil, in all treatments under SW application. CFU and SBR were the most effective variables in obtaining results and in the treatment discrimination. The dose with the best metabolic performance was $160 \mathrm{~m}^{3}$ ha-1 due to the better relationship of the parameters previously evaluated in this study.

\section{Atributos microbiológicos de um solo sob histórico de aplicação de água residuária de suínos}

RESUMO: Este trabalho buscou estudar o efeito da aplicação de água residuária de suínos (ARS) sobre os atributos microbiológicos de um solo argiloso cultivado com pinhão-manso (Jatropha curcas L.). Esta área experimental foi submetida a aplicações de ARS por 3 anos seguido de um pousio por 2 anos. Em dezembro de 2017 foram feitas as coletas de solo, 0 experimento foi conduzido em blocos completos casualizados (DBC) com seis tratamentos e três repetições, a saber: T1: 0 (testemunha), T2: 40, T3: 80, T4: 120, T5: 160 e T6: $200 \mathrm{~m}^{3}$ ha-1$^{-1}$. Os atributos avaliados foram: UFC, diversidade, CBM, RBS, $\mathrm{qCO}_{2}$ e FDA. Os valores das médias de UFC demonstraram incremento da densidade populacional bacteriana e a diversidade apontou o favorecimento de morfotipos bacterianos já presentes no solo, em todos os tratamentos sob aplicação de ARS. As variáveis mais efetivas para a obtenção dos resultados e discriminação dos tratamentos, foram a UFC e a RBS. A dose de melhor desempenho metabólico foi a de $160 \mathrm{~m}^{3}$ ha-1 devido a melhor relação dos parâmetros até então avaliados neste trabalho. 


\section{Introduction}

The global food demand has been exponentially growing and meat consumption has been the main source of consuming protein (Good, 2019). Brazil is considered as one of the largest pork producers, with the generation chain concentrated in its southern region (ABPA, 2017). The state of Paraná has the largest national breeding stock and its western region is considered as the largest representative, with the cities of Cascavel and Toledo as the main cores, holding altogether about $65 \%$ of the gross value of all state production (ABPA, 2017; Gervásio, 2018).

The great pork meat yield all over Brazil is mostly due to an intensive rearing based on containment systems; however, this management type produces a large waste amount. This has caused problems for both urban and rural societies alike, since the uncontrolled destination of these wastes has been contaminating groundwater, rivers and drinking-water sources, especially in thr meat-producing regions (Lourenzi et al., 2013; Balota, 2017).

Some studies estimate a maximum dose that can be applied to the soil without causing environmental impacts from the phosphorus content found in the organic waste (Sacomori et al., 2016, 2014; Sediyama et al., 2016). Nevertheless, the misuse of wastes has been frequent, since its access directly occurs between animal producers and farmers, and they are often the same; therefore, these wastes are not always subjected to chemical analysis prior to their application on the crops (Balota, 2017).

Yet another relevant factor to be considered in this form of production is its need for ample use of water in order to keep the breeding stock healthy, which has produced high waste volume in liquid form. These values are around $8.6 \mathrm{~L}$ per animal and this burden is responsibility of the producers in the western state of Paraná (Pinto et al., 2014; Frigo et al., 2015).

With this in mind, applying SW appears as a solution for both problems because, in addition to reusing water, it also promotes the use of waste as nutrients (Silva et al., 2014). Through this fertilization method, nutrients are made available early to the soil-plant system because the macro and micronutrients are already dissolved, incorporated by the soil solution when under appropriate conditions and in function of the soil type (Balota et al., 2014; Balota, 2017).

These organic compounds, rich in carbon sources and microorganisms, can promote physical, chemical and mainly biological changes in the environment (Sediyama et al., 2016). When applied to soils under cultivation, these wastes integrate new individuals into the system that request, from the natural microbiome, density and diversity adjustments between the species and their metabolic and structural functions (Balota, 2017),

Therefore, for a better environmental monitoring, Nogueira et al. (2015) propose using bioindicators, since the microorganisms are closely related to the functioning of the soil, playing a close interrelation with the physical and chemical components. Using a set of microbiological indicators in the quality evaluation of agricultural soils has been ideal, due to its sensitivity in detecting changes earlier in the environment in function of its use and management (Cardoso \& Andreote, 2016).

Therefore, the present study obtained values of microbiological attributes of an Ultisol from the western Paraná, cultivated with physic nut (Jatropha curcas L.) and subjected to fertilization with swine wastewater for 3 years and then to fallow for other two years. The aim was to determine the microbial quality of soils under different SW application doses after a long rest period and to evaluate which attributes best discriminated the treatments.

\section{Materials and Methods}

The experimental area is at the Adroaldo Augusto Colombo State Agricultural School (CAEAAC), located in Western Paraná, city of Palotina - PR. According to the Köppen classification (Climate-Data.Org, 2019), this region is characterized by the humid subtropical (Cfa) climate, with hot summers and cold winters, having an average annual rainfall of $1800 \mathrm{~mm}$. The region soil is classified, according to Embrapa, as a "Latossolo Vermelho Eutroférrico" (Ultisol) with clayey texture (Santos et al., 2018a).

The physic nut (Jatropha curcas L.) was set up in an area of $900 \mathrm{~m}^{2}$ divided into eighteen plots with a spacing of $4 \times 3$ $\mathrm{m}$, having four plants per plot. The experiment was conducted in randomized complete blocks (RCB), with the plots divided into three blocks with the control (T1) and five more different SW dosages: T2-40, T3-80, T4-120, T5-160 and T6-200 $\mathrm{m}^{3} \mathrm{ha}^{-1}$. The distribution was set by drawing, respecting the degree of freedom.

Nine SW applications were made in these areas, distributed over 3 years. The first application period was in December 2011 and repeated in March and June 2012. In 2013 and 2014, new applications were made respecting the same period set by the crop cycle. The obtained wastes did not receive any kind of previous treatment, stored directly in manure pits after their collecting in the stalls, where the pigs were on the fattening stage. The applications were carried out manually, with PVC watering cans with a capacity for $10 \mathrm{~L}$, in all management years.

The soil sampling was in December 2017 with the aid of an auger at a $0-10 \mathrm{~cm}$ depth. In each plot, five subsamples were collected from traces made diagonally according to the slope and homogeneity of the terrain (Dionísio et al., 2016). These subsamples were then homogenized and 18 composite samples were obtained, which were kept in expanded polystyrene with ice and sent to the Laboratory of Genetic Improvement, Plant and Soil Biotechnology at the Federal University of Paraná - Palotina Sector.

In order to obtain the isolates and count the pure colonies, the method of Dionísio et al (2016) was employed, where the heavy soil was dissolved in a saline solution for obtaining serial dilutions. Plating was performed in triplicate at the $10^{-3}$ 
concentration in a Dygs culture medium (Dobereiner et al., 1995) and grown inside a BOD at a temperature of 27 ㅇ $\mathrm{C}$ for 72 hours. The isolated cells considered as pure were evaluated by the CFU method (Colony-Forming Units). The morphological diversity was obtained from the characterization of isolated colonies according to Höfling \& Gonçalves (2011), but modified considering the following morphological characteristics: size (small, medium or large), shape (circular, irregular or rhizoid), border (smooth, lobed, spiral or wavy), homogeneity (homogeneous or heterogeneous), color (colorless or pigmented), brightness (transparent, translucent or opaque ), elevation (convex, flat, elevated, papillate or crateriform), structure (smooth, grainy, filamentous or rough) and appearance (smooth, grainy, filamentous or rough).

For obtaining the metabolic attributes in triplicate, initially the soil was sieved in a 2-mm-mesh and the moisture was determined by the gravimetric method. The microbial-biomass carbon (MBC) was obtained through the process of fumigation and extraction, where the samples were pre-incubated and fumigated with following extraction of carbon (C), as proposed by Vance et al. (1987). The soil basal respiration (SBR) was determined with the method of Jenkinson \& Powlson (1976), which consists of incubating the samples for ten days with 1 $\mathrm{M} \mathrm{NaOH}$ and titration with $0.5 \mathrm{M} \mathrm{HCl}$. The enzymatic activity was determined by the method of the fluorescein diacetate (FDA) hydrolysis, according to Schuner \& Rosswall (1982), in this method the soil was incubated with $60 \mathrm{mM}$ potassium phosphate buffer FDA solution ( $\mathrm{pH} 7.6)$ and the reading was made on an absorbance spectrophotometer $490 \mathrm{~nm}$. The organic carbon quotient $\left(\mathrm{qCO}_{2}\right)$ was obtained by the ratio between SBR per MBC unit.

All variables were obtained by following the experimentation principles, respecting both field and laboratory replicates. The values of CFU, MBC, SBR, FDA and $\mathrm{qCO}_{2}$ were subjected to analysis of variance (ANOVA) and multivariate analysis by the principal component technique (PCA), using the RStudio 3.5.0 software. The data of the morphological characterization were subjected to clustering analysis per category by employing the UPGMA algorithm with the software Bionumerics 7.5. The independent variables were compared to each other by Pearson correlation by using the RStudio 3.5 .0 software.

\section{Results and Discussion}

The acquisition of the microbial density, according to Dionísio et al (2016), is through the number of isolated colonies considered as pure and hailing from a single active and/or viable cell from the stipulated dilution. In the present study, from the means obtained for the CFU values in the $10^{-3}$ dilution, there was a small increase in the number of individuals in all treatments under application when compared to the control (Table 1). The method of counting colony-forming units is widely accepted and used in most

Table 1. Morphological groupings obtained after the characterization based on the morphological typing established by the category analysis employing the UPGMA algorithm.

\begin{tabular}{|c|c|c|c|c|c|c|c|}
\hline $\mathrm{AG}$ & $\mathrm{T} 1$ & T2 & T3 & T4 & T5 & T6 & Total \\
\hline G1 & 12 & 15 & 14 & 18 & 15 & 19 & 93 \\
\hline G2 & 1 & 4 & 6 & 1 & 2 & 4 & 18 \\
\hline G3 & 0 & 8 & 1 & 0 & 7 & 0 & 16 \\
\hline G4 & 3 & 0 & 4 & 4 & 0 & 7 & 18 \\
\hline G5 & 3 & 0 & 3 & 0 & 0 & 2 & 8 \\
\hline G6 & 0 & 0 & 0 & 0 & 4 & 1 & 5 \\
\hline G7 & 0 & 0 & 0 & 0 & 0 & 2 & 2 \\
\hline G8 & 0 & 0 & 0 & 2 & 0 & 0 & 2 \\
\hline G9 & 0 & 0 & 0 & 1 & 0 & 0 & 1 \\
\hline G10 & 0 & 0 & 0 & 1 & 0 & 0 & 1 \\
\hline G11 & 0 & 1 & 0 & 0 & 0 & 0 & 1 \\
\hline G12 & 0 & 0 & 0 & 0 & 1 & 0 & 1 \\
\hline G13 & 0 & 0 & 0 & 0 & 1 & 0 & 1 \\
\hline G14 & 0 & 0 & 0 & 0 & 1 & 0 & 1 \\
\hline G15 & 0 & 0 & 0 & 0 & 1 & 0 & 1 \\
\hline G16 & 0 & 0 & 0 & 0 & 0 & 1 & 1 \\
\hline G17 & 0 & 0 & 0 & 0 & 0 & 1 & 1 \\
\hline G18 & 0 & 0 & 1 & 0 & 0 & 0 & 1 \\
\hline G19 & 0 & 0 & 1 & 0 & 0 & 0 & 1 \\
\hline G20 & 0 & 0 & 1 & 0 & 0 & 0 & 1 \\
\hline G21 & 1 & 0 & 0 & 0 & 0 & 0 & 1 \\
\hline G22 & 1 & 0 & 0 & 0 & 0 & 0 & 1 \\
\hline G23 & 1 & 0 & 0 & 0 & 0 & 0 & 1 \\
\hline Total & 22 & 28 & 31 & 27 & 32 & 37 & 177 \\
\hline CFU & $6.83 \times 10^{4}$ & $7.03 \times 10^{4}$ & $8.09 \times 10^{4}$ & $7.40 \times 10^{4}$ & $8.94 \times 10^{4}$ & $8.43 \times 10^{4}$ & \\
\hline CV\% & $9.1 \%$ & $4.8 \%$ & $18.1 \%$ & $13.8 \%$ & $11.5 \%$ & $26.8 \%$ & \\
\hline
\end{tabular}

*AG: Morphological groupings; T1: Control; from T2 to T6: 40, 80, 120, 160 and $200 \mathrm{~m}^{3}$ ha $^{-1}$ respectively; CFU: Colony-Forming Units given in g soil ${ }^{-1}$; CV\%: CFU coefficient of variation Total: Total of isolated individuals who composed each group. 
methodologies aiming quality control of some biological product and/or diagnosing the living condition of a soil after using organic residues (Moreira \& Siqueira, 2006; Pinto et al., 2019). Therefore, even after 2 years of resting, it is noted that, at the different doses, it was possible to maintain the attained biological gains with managed SW applications for 3 consecutive years in the physic nut area.

Morphological diversity revealed that SW applications, regardless of the dosage, favored the predominance of certain already existing morphotypes in the soil. From the morphological typing (Table 1), it was possible to observe the formation of 23 groups (from G1 to G23), considering all treatments and the control. G1 was the group with the highest number of grouped individuals (93 out of 177) due to a high similarity (93\%). The groupings from G2 to G6 had 18, 16, 18,8 and 5 isolates, respectively. When observing the other groups, there is a marked reduction in the isolates number. As for groups G7 and G8, there are only two isolates while for the other groups, from $G 9$ to $G 23$, each one has the insertion of unique individuals

Continuing on Table 1, when observing the different groups (from G1 to G23) in relation to the treatments, it is possible to verify that the control (T1) had 7 different groups; followed by 8 groups for T3, T5 and T6; 4 groups for T2; and 6 groups for T4 . Initially, for T3, T5 and T6, this is because, in the organic residues of animals, there are a number of specific microorganisms in large quantities that are additional to the density and diversity of the natural soil biota (Körber et al., 2020). The smaller number of distinct groups found in $\mathrm{T} 2$ (40 $\left.\mathrm{m}^{3} \mathrm{ha}^{-1}\right)$, can be explained if this application is considered a sub-dose when compared to treatments T5 and T6. In the studies by Lalande et al. (2000) and Ceretta et al. (2003), the values of 30 and $40 \mathrm{~m}^{3}$ ha $^{-1}$ were considered as sub-doses, respectively.

When identifying bacteria isolated from anaerobic digesters operated with swine manure, Moura (2017) verified the predominance of bacteria from the genus Bacillus and Enterobacter. On the other hand, Schmidt (2002) identified Bacillus and Pseudomonas in stabilization ponds. In most of the diversity studies conducted in productive Ultisols, the genera found in greater quantity are Bacillus, Enterobacter and Pseudomonas (Cardoso \& Andreote, 2016). In studies such as the ones from Moura et al. (2016) and Toniazzo et al. (2018), it was possible verifying that the prolonged use of SW not only stimulated the permanence of resilient beings in the soil, but also inserted new microorganisms that are incorporated over time in the biota, permanently being part of this edaphic fauna group.

A descriptive analysis of the data contained in this study demonstrated that, for microbiological variables, even though consisting of field replicates, their mean values were always similar or greater than the median, thus, their distributions for $\mathrm{MBC}, \mathrm{SBR}, \mathrm{qCO}_{2}, \mathrm{CFU}$ and FDA are considered symmetrical, although the $\mathrm{qCO}_{2}$ attribute does not have a normal distribution (Table 2). According to the ANOVA, there was no significant difference at $5 \%$ between the evaluated attributes due to the high data variability.

In studies with microorganisms, these variations are normally expected to be found because they are considered as extremely sensitive to abiotic and anthropic factors (Amaral et al., 2013). Most of the statistical tools commonly used for analyzing agronomic data, when applied in a study with microorganisms, reveal high values for the coefficient of variation, for example (Souza et al., 2008).

It is often more recommended to evaluate microbial data from non-parametric tests, since these have the advantage of allowing studying, in terms of significance, the data that are inherently classified (nominal scale) or presented in ranks (ordinal scale) (Montgomery \& Runger, 2016). However, when analyzing the curve of each microbiological attribute in each treatment, it is possible to verify that SW had influence on the microbiological soil attributes (Figure 1).

The microbial biomass carbon of the soil is an attribute of great importance since it is able to reflect any change that occurs in the organic matter of the soil, corresponding to from about 25 to $30 \%$ of it, mainly in farmlands (Moreira \& Siqueira, 2006). From the $M B C$ values found in Figure $1 A$, the general mean obtained in this study was of $126.80 \mathrm{mg} \mathrm{C} \mathrm{kg}^{-1}$ soil. This

Table 2. Descriptive statistics for the microbiological attributes of the soil in the experimental planting area of physic nut in Western Paraná on the sum of all treatments, namely the control (T1), 40 (T2), 80 (T3), 120 (T4), 160 (T5) and 200 (T6) $\mathrm{m}^{3}$ ha $^{-1}$ of swine wastewater (SW).

\begin{tabular}{|c|c|c|c|c|c|}
\hline & $\begin{array}{c}\mathrm{MBC} \\
\text { (mg C kg-1 soil) } \\
\end{array}$ & 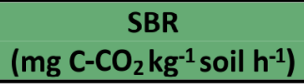 & 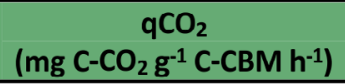 & $\begin{array}{c}\text { CFU } \\
\left(\text { (g soil }^{-1}\right) \\
\end{array}$ & $\begin{array}{c}\text { FDA } \\
\left(\text { (mg hydrolyzed FDA kg soil }{ }^{-1}\right)\end{array}$ \\
\hline Minimum & 41.98 & 0.04 & 0.49 & $5.86 \times 10^{4}$ & 167.9 \\
\hline Maximum & 220.54 & 0.43 & 11.34 & $10.09 \times 10^{4}$ & 338.3 \\
\hline First Quartile & 96.50 & 0.14 & 0.81 & $6.83 \times 10^{4}$ & 229.2 \\
\hline Median & 113.99 & 0.23 & 1.35 & $7.22 \times 10^{4}$ & 250.0 \\
\hline Mean & 121.47 & 0.22 & 2.22 & $7.79 \times 10^{4}$ & 255.1 \\
\hline Third Quartile & 162.26 & 0.28 & 2.58 & $8.93 \times 10^{4}$ & 275.0 \\
\hline Asymmetry & 0.01 & 0.36 & 2.67 & 1.02 & 0.24 \\
\hline Kurtosis & 2.01 & 2.71 & 10.03 & 3.75 & 2.52 \\
\hline CV (\%) & 52.85 & 45.79 & 115.56 & 45.56 & 18.01 \\
\hline p-value & $0.98 \mathrm{~ns}$ & $0.63 \mathrm{~ns}$ & $0.83 \mathrm{~ns}$ & $0.31 \mathrm{~ns}$ & $0.75 \mathrm{~ns}$ \\
\hline
\end{tabular}

* MBC: Soil microbial biomass carbon; SBR: Soil basal respiration; $\mathrm{qCO}_{2}$ : metabolic quotient; CFU: Colony-Forming Units; FDA: fluorescein diacetate; ** CV: Coefficient of variation; p-value: not significant by the ANOVA parametric test at $5 \%$. 
Microbian Biomass Carbon (MBC)

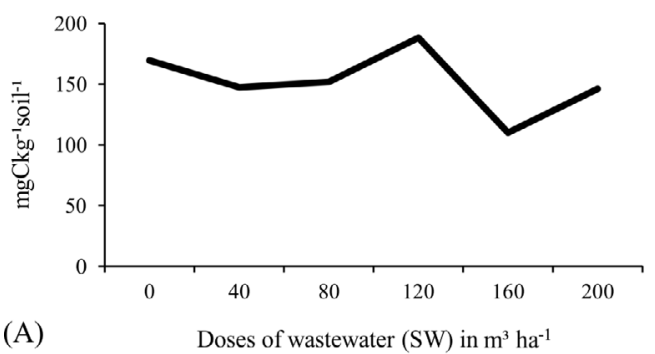

Metabolic quotient

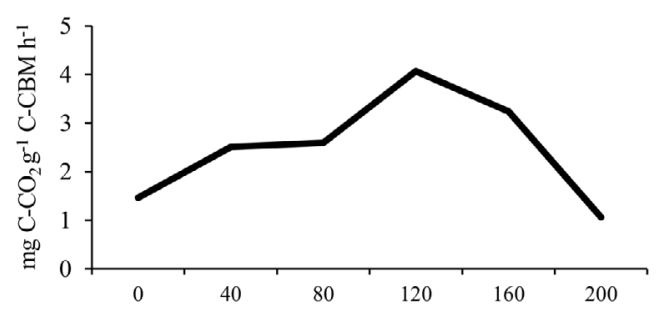

(C)
Soil Basal Respiration (SBR)

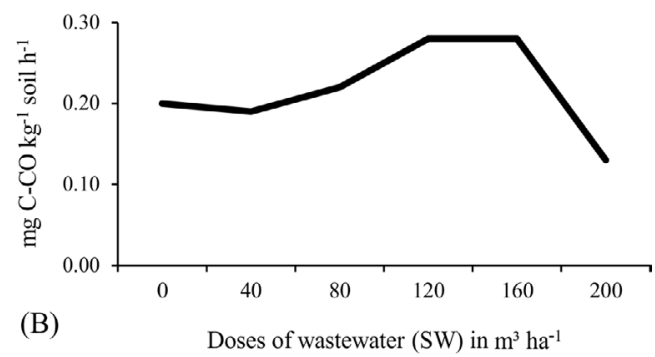

Fluorescein hydrolysis (FDA)

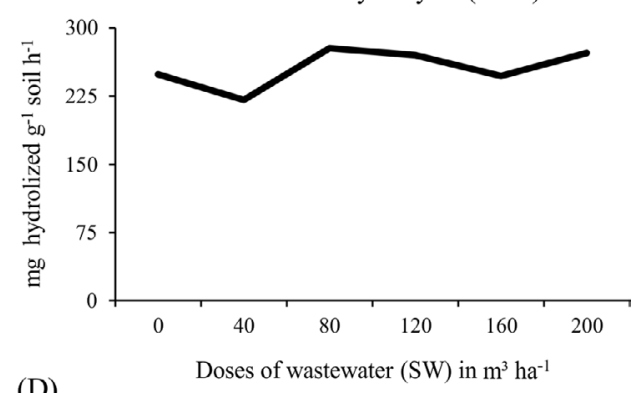

(D)

Colony-Forming Units (CFU)

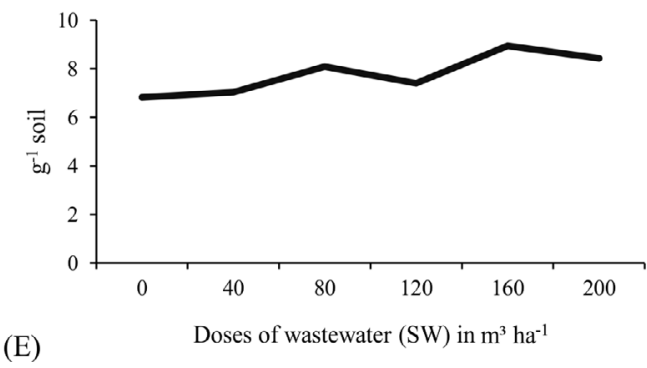

Figure 1. Curves of microbiological attributes, $A . M B C, B . S B R, C$. $q C C_{2}, D$. FDA and E. CFU, based on the mean of the data obtained for each treatment of different dosages of wastewater (SW).

value is commonly found in the soil type of the region (Ultisol) in perennial crops or in uncovered soils (Novak et al., 2017).

Even when considering only the doses from treatments T2-40, T3-80 and T6-200 $\mathrm{m}^{3} \mathrm{ha}^{-1}$, there is also little variation, with these same treatments having a mean around $148.46 \mathrm{mg}$ $\mathrm{C} \mathrm{kg}^{-1}$ soil; however, this value was below the MBC found in T1 (169.93 $\mathrm{mg} \mathrm{C} \mathrm{kg}^{-1}$ soil) with no application. In general, the low MBC values found for all treatments are due to the lack of general and agronomic management of the experimental area. For the proper cultivation of perennials, it is widely recommended to plant green coverage between the rows for reducing the temperature, mitigating compaction, avoiding erosion and improving the soil absorption of nutrients (Fidelis et al., 2016).

In the treatment T5 (110.04 $\mathrm{mg} \mathrm{C} \mathrm{kg}^{-1}$ soil) was the lowest $\mathrm{MBC}$ value found while T4 was the one that favored the soil biota the most, also the only one that surpassed the control (188.13 $\mathrm{mg} \mathrm{C} \mathrm{kg}^{-1}$ soil) after two years of soil resting. The reduction in the $\mathrm{MBC}$ value for $\mathrm{T5}$ is probably due to the lack of homogenization of the waste, which was also used in excess in some applications in this area over the previous 3 years. Studies point out that, under high organic waste doses, the soil receives exceeding amounts of micronutrients, compromising the microbial activity either by reducing the decomposition time or by recalcitrating the elements in the rhizospheric system (Souza et al., 2016)

In their studies on MBC values, Amaral et al. (2011) also found around $127 \mathrm{mg} \mathrm{C} \mathrm{kg}{ }^{-1}$ soil in vine, which has a management similar to that of physic nut due to the existence of uncovered soil. Balota et al. (2014) found that the addition of average SW doses of $100 \mathrm{~m}^{3} \mathrm{ha}^{-1}$ over 15 years provided an increase of the microbial biomass of the soil of more than $50 \%$, in an area of no-tillage. This considerable increase is due to the capacity that this waste type has, not only to insert microorganisms, but also to supply nutrients that serve as an energy source for biota (Balota, 2017). On the other hand, when applying very high doses, as in the studies of Lourenzi et al. (2013) and Rath \& Rousk (2015), the soil biological 
saturation can occur, thus reducing the $\mathrm{MBC}$ and consequently delaying the decomposition rate.

Soil basal respiration (SBR) is closely related to the metabolic activity of the microbial community dependent on biotic and abiotic factors (Moreira \& Siqueira, 2006). In this same study, the authors verified low values and little variation between the SBR data in treatments T1, T2 and T3 $(0.20 ; 0.19$ and $0.22 \mathrm{mg} \mathrm{C}^{-} \mathrm{CO}_{2} \mathrm{~kg}^{-1} \mathrm{soil} \mathrm{h}^{-1}$ ) (Figure $1 \mathrm{~B}$ ). This low variation corroborates with the $\mathrm{MBC}$ values found for these same treatments, which also did not differ from each other.

According to Cardoso \& Andreote (2016), with the less carbon lost as $\mathrm{CO}_{2}$ by the respiration, the more significant is its incorporation into the microbial biomass. In long-term organic fertilization studies, SBR has been noted to stabilize itself in soils under frequent organic fertilization (Lalande et al. , 2000; Balota et al., 2014). Considering the treatments in the doses of 160 (T5) and 200 (T6) $\mathrm{m}^{3} \mathrm{ha}^{-1}$ of swine wastewater (SW), it is possible to point out that in these be a better carbon conversion may be happening. The $\mathrm{qCO}_{2}$ values for these treatments corroborate in this regard, as they (Figure 1C) present a curve reduction.

According to Balota et al. (2014), low waste doses promote minimal changes in attributes that are difficult to differentiate by the employed methods. It is possible that, in these conditions, the natural community did not receive enough external stimulus to promote changes in its metabolic activity. On the other hand, such effects can be seen in methods that detect the mineralization of nutrients like carbon and nitrogen (Balota, 2017).

Higher SBR values were found for treatments T4 and

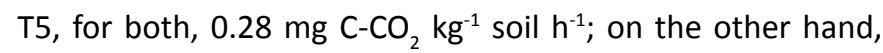
a drastic drop was observed in the SBR value for T6 $10.13 \mathrm{mg}$ $\mathrm{C}-\mathrm{CO}_{2} \mathrm{~kg}^{-1}$ soil $\left.\mathrm{h}^{-1}\right)$. This variation may be directly related to the carbon supply from SW to the soil. Large dosages insert a high amount of labile carbon into the soil, promoting an increase in metabolic activity; however, when observing the treatment T6 (dosage of $200 \mathrm{~m}^{3} \mathrm{ha}^{-1}$ ), it is assumed that there was an excessive insertion of some nutrient and/or heavy metals which then inhibited the activity of some more specific and sensitive groups (Etesami, 2018).

The metabolic quotient $\left(\mathrm{qCO}_{2}\right)$ is a factor that represents the efficiency of microorganisms in using carbon as an energy source. Balota (2017), reports that lower quotients denote the environment stability, as long as SBR is decreasing, as well as higher quotients are related to possible environmental stresses. Therefore, good $\mathrm{qCO}_{2}$ values are those that are lower and correlated with a stable SBR and high MBC values (Cardoso \& Andreote, 2016).

Generally, in this study, it was found a high $\mathrm{qCO}_{2}$ mean (range from 0.89 to 4.28 ) in relation to other studies with the same crop. Fidelis et al. (2016) found $\mathrm{qCO}_{2}$ values from 0.25 to 0.75 , both in the physic nut consortium with legumes and in its single planting. Santos et al. (2018b), for the same plant, obtained values of $\mathrm{qCO}_{2}$ ranging from 0.46 to 0.64 ; however, in both studies the fertilization performed was the mineral kind.
The belief is that these variations, mainly of $\mathrm{qCO}_{2}$, are due to the population adjustment that is still occurring in this soil after two years of fallow and lack of conventional management. Uncovered soils have trouble maintaining the stability of the bacterial community activity due to the oscillation of abiotic factors such as temperature and humidity (Frenk et al., 2018).

The analysis of the hydrolysis of fluorescein diacetate (FDA) has been standing out since it is a technique capable of quantifying the enzymatic activity from three enzymes: protease, esterase and lipase. These have great importance in the soil because, when a large amount of organic matter is inserted into it, they are the main enzymes to act, widely accepted as a soil indicator (Ribeiro et al., 2015).

In the present study, the FDA values of the soil practically did not demonstrate changes (Figure 1D) when comparing the treatments under SW application with the control. Such balance refers to the soil ability in remaining stable over time, even after performing managements that are more incisive by using slightly high SW doses (T4, T5 and T6). For Ribeiro et al. (2015), the FDA is considerably changed only after the moment of a great organic matter deposition in the soil, which does not apply to this study, considering the interval between the moment of the last application and the period of soil collection.

When performing the Pearson analysis (Table 3), observing a strong positive correlation between SBR and $\mathrm{qCO}_{2}$ (0.669) was possible, with this denoting the proportional relation of these attributes mentioned, since both depend directly on biotic and abiotic factors (Balota et al., 2014). The $\mathrm{qCO}_{2}$ demonstrated a negative correlation with $\mathrm{MBC}$ of -0.611 , corroborating with several studies available in the literature stating that the higher the microbial biomass quality is, the better the carbon conversion efficiency will be and the faster the soil will return to its natural stability (Nogueira et al., 2015; Dionísio et al., 2016; Balota, 2017).

The negative correlation of CFU with $\mathrm{qCO}_{2}(-0.423)$ and SBR $(-0.375)$ may be demonstrating that, with the greater population density of a soil, the greater also is the possibility of it being under intense metabolic activity in the rhizosphere, be it either by competition for food, antagonisms, symbiotic relationships with plants, among others (Moreira \& Siqueira, 2006; Nogueira et al., 2015).

Such fact directly reflects on $\mathrm{qCO}_{2}$, exposing the predominance of resilient microorganisms in this soil, that

Table 3. Pearson correlation coefficients among the microbiological attributes of microbial biomass carbon (MBC), soil basal respiration (SBR), metabolic quotient $\left(\mathrm{qCO}_{2}\right)$, colonyforming units (CFU) and fluorescein diacetate (FDA) units subjected to different dosages of swine wastewater (SW).

\begin{tabular}{cccccc}
\hline Variables & SBR & MBC & $\mathrm{qCO}_{2}$ & CFU & FDA \\
\hline SBR & 1 & -0.129 & 0.669 & -0.375 & 0.025 \\
$\mathrm{MBC}$ & -0.129 & 1 & -0.611 & 0.233 & 0.221 \\
$\mathrm{qCO}_{2}$ & 0.669 & -0.611 & 1 & -0.423 & -0.177 \\
$\mathrm{CFU}$ & -0.375 & 0.233 & -0.423 & 1 & 0.168 \\
$\mathrm{FDA}$ & 0.025 & 0.221 & -0.177 & 0.168 & 1 \\
\hline
\end{tabular}




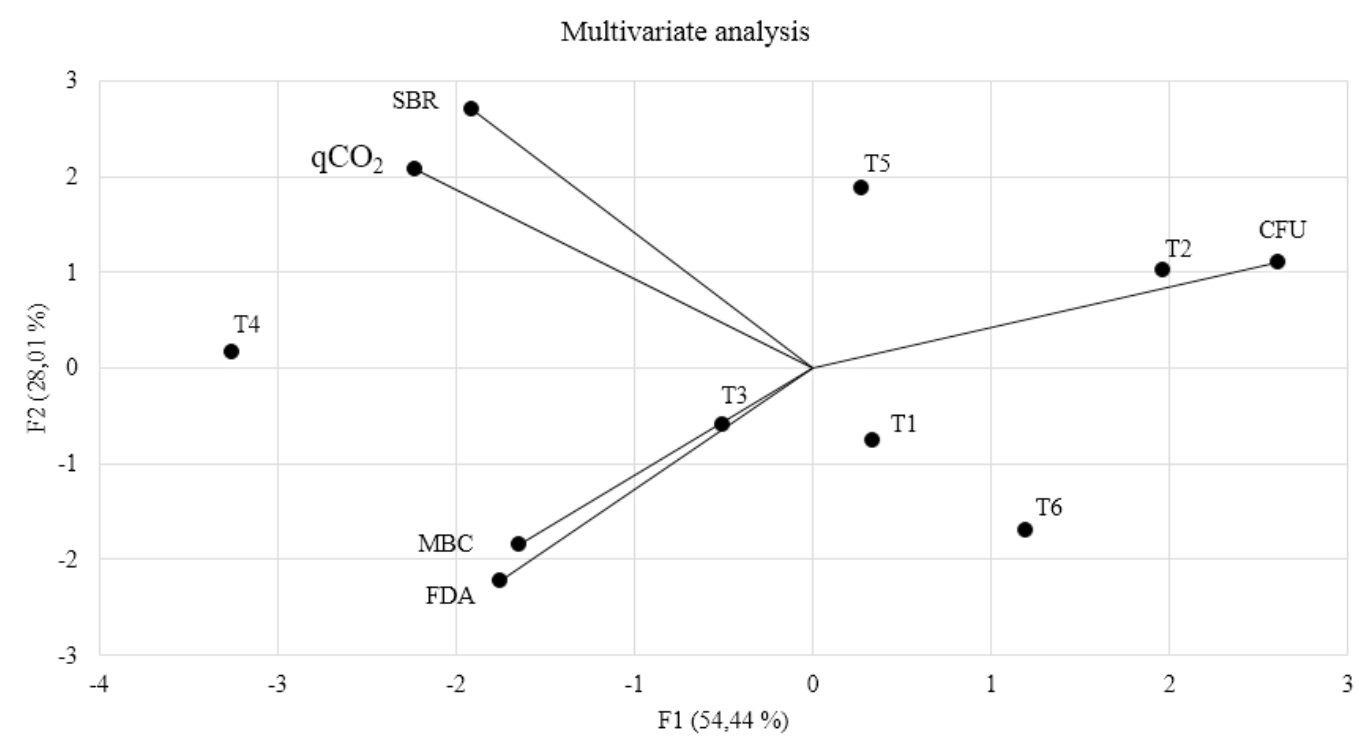

Figure 2. Principal component analysis (PCA) for microbiological attributes of the soil obtained from an experimental area under the cultivation of physic nut in Western Paraná, which was subjected to different dosages of swine wastewater (SW), namely T1 (Control), T2 $\left(40 \mathrm{~m}^{3} \mathrm{ha}^{-1}\right)$, T3 $\left(80 \mathrm{~m}^{3} \mathrm{ha}^{-1}\right)$, T4 $\left(120 \mathrm{~m}^{3} \mathrm{ha}^{-1}\right)$, T5 $\left(160 \mathrm{~m}^{3} \mathrm{ha}^{-1}\right)$ and T6 $\left(200 \mathrm{~m}^{3} \mathrm{ha}^{-1}\right)$ * MBC: Microbial biomass carbon, SBR: Soil basal respiration, $\mathrm{qCO}_{2}$ : metabolic quotient, $\mathrm{CFU}$ : colony-forming units, FDA: fluorescein diacetate hydrolysis.

is, the occurrence of the lowest maintenance of the bacterial community (mean of $10^{4} \mathrm{CFU} g$ soil $^{-1}$ ) with a moderate metabolic activity $\left(2.22 \mathrm{mg} \mathrm{C}-\mathrm{CO}_{2} \mathrm{~g}^{-1} \mathrm{C}-\mathrm{MBC} \cdot \mathrm{h}^{-1}\right)$ due to more stable material existing (Anderson \& Domsch, 2010; Balota, 2017). Thereby, even after two years with no fertilization in the area, the SW allows the constant metabolism of macros and micronutrients by the biota due to its soil chemicalstabilization capacity (Ceretta et al., 2003).

The PCA enabled discriminating $92.72 \%$ of the components that were most relevant in obtaining comparative results. Principal component 1 (PC1) and principal component 2 (PC2) made up together $82.33 \%$ of the total data variance. PC1 had $54.26 \%$ of the total variance and PC2 had $28.08 \%$ (Figure 2), pointing out that, respectively, the attributes CFU and SBR were the ones that better discriminated this study data.

Through the ACP, the formation of two groups in relation to the treatments is observed, with the first one represented by the T4 treatment $\left(120 \mathrm{~m}^{3} \mathrm{ha}^{-1}\right)$ and the second one containing the remaining. A similar behavior was also noted between the variables of the attributes FDA and $\mathrm{MBC}$, demonstrating a strong association with the effects caused by the T3 treatment $\left(80 \mathrm{~m}^{3}\right.$ $\left.\mathrm{ha}^{-1}\right)$. However, the reverse CFU behavior is highly associated with the results found in the $\mathrm{T} 2$ treatment $\left(40 \mathrm{~m}^{3} \mathrm{ha}^{-1}\right)$.

The CFU relation with the other variables is not a commonly encountered situation, as it belongs to MBC along other beings like fungi, algae and protozoa. Even so, in cultivated systems, the maintenance of metabolic activities is linked directly to the cycles of the main elements involved with yield (Moreira \& Siqueira, 2006; Cardoso \& Andreote, 2016).

In agricultural managements, environmental services can be enforced by a community composed of individuals, both selected and resilient, who are able of, through a modified and/or acquired genetic apparatus, over time and under different situations of selective pressure, performing tasks involved in obtaining, mainly from carbon, nitrogen and phosphorus (Etesami, 2018).

In the present study, the treatments with wastewater doses from 40 to $200 \mathrm{~m}^{3} \mathrm{ha}^{-1}$ made possible verifying that applying organic waste interfered in the structure of the soil microbial communities, even after two years of resting. The evaluated attributes managed to point out the $160 \mathrm{~m}^{3} \mathrm{ha}^{-1}$ dose as the most positive anthropic interference and that the excess carbon $\left(200 \mathrm{~m}^{3} \mathrm{ha}^{-1}\right)$ can inhibit key enzymatic activities, thus leading the biota to wearing and losing diversity. Therefore, monitoring the wastewater-application technology is necessary for generating regional data that help the producer to properly manage the generated waste on his properties, allowing the safe management of adequate doses of these organic fertilizers in the agricultural production.

\section{Conclusion}

There was an increase in the bacterial population density in the treatments managed with the application of swine wastewater (SW);

In all treatments under fertigation, the diversity of bacterial morphotypes already present in the soil was favored;

The most effective variables for obtaining the results and treatment discrimination were the colony-forming units (CFU) and the soil basal respiration (SBR).

The dose with the best metabolic performance was $160 \mathrm{~m}^{3}$ $\mathrm{ha}^{-1}$ (T5) due to the better relationship between the evaluated parameters so far.

\section{Acknowledgements}

The present study was conducted with the support of the Coordination for the Improvement of Higher Education Personnel - Brazil (CAPES) - Financing code 001. 


\section{Literature Cited}

Amaral, H. F.; Sena, J. O. A.; Schwan-Estrada, K. R. F.; Balota, E. L.; Andrade, D. S. Soil chemical and microbial properties in vineyards under organic and conventional management in Southern Brazil. Revista Brasileira de Ciência do Solo, Viçosa, v. 35, n. 5, p. 1517-1526, 2011. http://dx.doi.org/10.1590/S0100-06832011000500006

Amaral, H. F.; Yada, I. F. U.; Vasconcellos, M. E. C. Revisão sistemática do panorama, fundamentos e aplicações da estatística univariada em microbiologia do solo. Terra e Cultura, v. 1, n. 56, p. 73-82, 2013. http://periodicos.unifil.br/index.php/Revistateste/article/ view/188.

Anderson, T. H.; Domsch, K. H. Soil microbial biomass: the ecophysiological approach, Soil Biology and Biochemistry, Elmsford, v. 42 , n. 12 , p. 2039-2043, 2010. https://doi.org/10.1016/j. soilbio.2010.06.026

Andrade, D. S.; Hamakawa, P. J. Estimativa do número de células viáveis de rizóbio no solo e em inoculantes por infecção em plantas. In: Hungria, M.; Araújo, R. S. (Eds.). Manual de métodos empregados em estudos de microbiologia agrícola. Brasília: Embrapa; SPI, 1994. p.63-94. (Embrapa-CNPAF. Documentos, 46). https://www.infoteca.cnptia.embrapa.br/infoteca/bitstream/ doc/199952/1/doc46.pdf. 10 Jan. 2019.

Associação Brasileira de Proteína Animal - ABPA. Relatório Anual 2017. Brasília: ABPA, 2017. 133p. http://abpa-br.org/wp-content/ uploads/2019/07/3678c_final_abpa_relatorio_anual_2017_ portugues_web_reduzido.pdf. 03 Jan. 2019.

Balota, E. L. Manejo e qualidade biológica do solo. Londrina: Mecenas Ltda, 2017. 288p.

Balota, E. L.; Machineski, O.; Hamid, K. I. A.; Yada, I. F. U.; Nakatani, A. S.; Barbosa, G. M. C.; Coyne, M. S. Soil microbial properties after long-term swine slurry and no-tillage systems in Brazil. Science of the Total Environment, v. 490, n.1, p. 397-404, 2014. https://doi. org/10.1016/j.scitotenv.2014.05.019.

Cardoso, E. J. B. N.; Andreote, F. D. Microbiologia do solo. Piracicaba: USP, 2016. 225p.

Ceretta, C. A.; Durigon, R.; Basso, C. J. Barcellos, L. A. R.; Vieira, F. C. B. Características químicas de solo sob aplicação de esterco líquido de suínos em pastagem natural. Pesquisa Agropecuária Brasileira, v. 38, n. 6, p.729-735, 2003. https://doi.org/10.1590/ S0100-204X2003000600009.

Climate-Data.Org. Brasil. Paraná. Assis Chateaubriand. http:// pt.climate-data.org/location/43679. 22 Jan. 2019.

Dionísio, J. A.; Pimentel, I. C.; Signor, D.; Paula, A. M. De; Maceda, A.; Mattana, A. L. Guia prático de biologia do solo. Curitiba: SBCS, 2016. 152p. https://ainfo.cnptia.embrapa.br/digital/bitstream/ item/142645/1/Diana-Signor-guia-pratico-biologia-solo.pdf. 19 Jan. 2019.

Dobereiner, J.; Baldani, V. L. D.; Baldani, J. I. Como isolar e identificar bactérias diazotróficas de plantas não-leguminosas. Seropédica: Embrapa Agrobiologia, 1995. 66p.

Etesami, H. Can interaction between silicone and plant growth promoting rhizobacteria benefit in alleviating abiotic and biotic stresses in crop plants. Agriculture, Ecosystems \& Environment, v. 253, n.1, p. 98-112, 2018. https://doi.org/10.1016/j. agee.2017.11.007.
Fidelis, R. R.; Alexandrino, C. M. Dos S.; Silva, D. B. Da.; Sugai, M. A. A.; Silva, R. R. da. Indicadores biológicos de qualidade do solo em culturas intercalares ao pinhão-manso. Brazilian Journal of Applied Technology for Agricultural Science, v. 9, n. 3, p.87-95, 2016. https://doi.org/10.5935/PAeT.V9.N03.10.

Frenk, S.; Hadas, Y.; Minz, D. Quality of irrigation water affects soil funcionality and bacterial community stability in response to heat disturbance, Applied and Environmental Microbiology, v. 84, n. 4, p. 1-14, 2018. https://doi.org/10.1128/AEM.02087-17.

Frigo, E. P.; Alves, H. J.; Frigo, M. S.; Araujo, C. H. C.; Bastos, R. K. Biomassa residual rural proveniente de diferentes atividades agropecuárias brasileiras. Energia na Agricultura, Botucatu, v. 30, n. 1, p. 21-26, 2015. http://dx.doi.org/10.5380/rber.v5i1.43916.

Gervásio, E. W. Suinocultura paranaense. Londrina: Secretaria do Estado da Agricultura e Abastecimento, 2018. 8p. http://www. agricultura.pr.gov.br/sites/default/arquivos_restritos/files/ qas/5578/informe_suinos_maio_17.pdf. 10 Jan. 2019.

Good, K. USDA-FAS Report: China's meat and poultry import forecast 2018: decline and constrained growth. https://farmpolicynews. illinois.edu/2017/10/usda-fas-report-chinas-meat-poultryimport-forecast-2018. 25 Jan. 2019.

Höfling, J. F.; Gonçalves, R. B. Microscopia de luz em microbiologia: morfologia bacteriana e fúngica. Porto Alegre: ArtMed, 2011. 244p.

Jenkinson, D. S.; Powlson, D. S. The effects of biocidal treatments on metabolism in soil - V: a method for measuring soil biomass. Soil Biology \& Biochemistry, v. 8, n. 3, p. 209-213, 1976. https://doi. org/10.1016/0038-0717(76)90005-5.

Körber, L. P. P; Freitas, G. P.; Hass, L. M; Amaral, H. F. Barreiros, M. A. B.; Frigo, E.; Grange, L. Diversidade bacteriana de um solo obtida ao longo de sucessivas aplicações de água residuária de suínos (ARS). In: Amaral, H. F.; Schwan-Estrada, K. R. F. (Eds.). Agricultura em bases agroecológicas e conservacionistas. Londrina: Atena, 2020. p.229-239. https://doi.org/10.22533/at.ed.07220210220.

Lalande, R.; Gagnon, B.; Simard, R. R.; Coté, D. Soil microbial biomass and enzyme activity following liquid hog manure application in a long-term field trial. Canadian Journal of Soil Science, v. 80, n. 2, p.263-269, 2000. https://doi.org/10.4141/S99-064.

Lourenzi, C. R; Ceretta, C. A.; Silva, L. S. da; Girotto, E.; Lorensini, F.; Tiecher, T. L.; Conti, L. de; Trentin, G.; Brunetto, G. Nutrients in soil layers under no-tillage after successive pig slurry applications. Revista Brasileira de Ciência do Solo, v. 37, n. 1, p.157-167, 2013. https://doi.org/10.1590/S0100-06832013000100016.

Montgomery; D. C.; Runger, G. C. Estatística aplicada e probabilidade para engenheiros. 6.ed. Rio de Janeiro: LTC Editora, 2016. 652p.

Moreira, F. M. S.; Siqueira. J. O. Microbiologia e bioquímica do solo. Lavras: UFLA, 626 p. abril, 2006.

Moura, A. C.; Sampaio, S. C.; Remor, M. B.; Silva, A. P. DA; Pereira, P. A. $M$. Long-term effects of swine wastewater and mineral fertilizer association on soil microbiota. Engenharia Agrícola, v. 36, n. 2, p. 318-328, 2016. https://doi.org/10.1590/1809-4430-Eng.Agric. v36n2p318-328/2016.

Moura, S. C. N. de. Identificação e perfil de susceptibilidade a antimicrobianos de bactérias isoladas de biodigestores anaeróbios operados com dejetos suínos e com dejetos bovinos. Juiz de Fora: Universidade Federal de Juiz de Fora, 2017. 74p. Dissertação Mestrado. https://repositorio.ufjf.br/jspui/handle/ ufjf/4595. 18 Jan. 2019. 
Nogueira, M. A.; Miyauchi, M. Y. H.; Bini, D.; Andrade, G. Microrganismos e processos microbianos como bioindicadores de qualidade ambiental. In: Yamada-Ogatta, S. F.; Nakazato, G.; Furlaneto, M. C.; Nogueira, M. A. (Eds.). Tópicos especiais em microbiologia. Londrina: UEL, 2015. Cap. 17, p. 262-281.

Novak; E.; Carvalho, L. A.; Santiago, E. F.; Portilho, I. I. R. Chemical and microbiological atributes under diferente soil conver. Cerne, v. 23 , n. 1, p. 19-30, 2017. https://doi.org/10.1590/0104776020 1723012228.

Pinto, L. P.; Cabral, A. C.; Schneider, L. T.; Azevedo, K. D. De.; Frigo, J. P.; Frigo, E. P. Levantamento de dados sobre os dejetos suínos e suas características. Revista Brasileira de Energias Renováveis, v. 3, n. 3, p. 179-187, 2014. https://doi.org/10.5380/rber.v3i3.38467.

Pinto, L. P.; Peruzzolo, M. C.; Hister, J. R. W. H.; Frigo, E. P.; Barreiros, M. A. B.; Grange, L. Alteração populacional e morfológicas da comunidade celulolítica de um solo sob aplicação de biofertilizante. Revista Brasileira de Energias Renováveis, v. 8, n. 2, p. 455-467, 2019. https://doi.org/10.5380/rber.v8i2.

Rath, K. M.; Rousk, L. Salt effects on the soil microbial decomposer community and their role in organic carbon cycling: a review, Soil Biology \& Biochemistry, v. 81, p. 108-123, 2015. https://doi. org/10.1016/j.soilbio.2014.11.001.

Ribeiro, T. S.; Cunha, P. Ö.; Silva, L. A. P. Avaliação do potencial de biorremediação de solos contaminados: método de hidrólise de diacetato de fluoresceína (FDA) como indicador de atividade microbiana. Revista Aquila, v.1, n.13, p. 105-120, 2015.

Sacomori, W.; Casso, P. C.; Ernani, P. R.; Miquelluti, D. J.; Comin, J. J.; Gatiboni, L. C. Concentração de nutrientes na solução do subsolo de lavoura fertilizada com dejeto suíno. Revista de Ciências Agroveterinárias, v. 15, p. 245-258, 2016. https://doi.org/10.59 65/223811711532016245.

Santos, A. A.; Agustini, J. A.; Maltoni, K. L.; Cassiolato, A. M. R. Addition of waste and introduction of microrganisms after 45 years of soil degradation. Revista Ciência Agronômica, v. 49, n. 3, p.363-370, 2018a. http://dx.doi.org/10.5935/1806-6690.20180041

Santos, H. G. Dos; Jacomine, P. K. T.; Anjos, L. H. C Dos; Oliveira, V. A. De; Lumbreras, J. F.; Coelho, M. R.; Almeida, J. A. De; Araujo Filho, J. C. De; Oliveira, J. B. De; Cunha T. J. F. Sistema brasileiro de classificação de solos. 5.ed. Brasília: Embrapa, 2018b. 356p.
Schmidt, V. Sobrevivência de microrganismos mesófilos e perfil físicoquímico em estação de tratamento de dejetos suínos. Porto Alegre: Universidade Federal do Rio Grande do Sul, 2002. 122p. Tese Doutorado. https://lume.ufrgs.br/handle/10183/3456. 12 Jan. 2019.

Schuner, J.; Rosswall, T. Fluorescein diacetate hydrolysis as a measure of total microbial activity in soil and litter. Applied and Environmental Microbiology, v.43, n. 1, p. 1256-1261, 1982. https://doi.org/10.1128/AEM.43.6.1256-1261.1982.

Sediyama, M. A. N.; Magalhães, I. P. B.; Vidigal, S. M.; Pinto, C. L. O.; Cardoso, D. S. C. P.; Fonseca, M. C. M.; Carvalho, I. P. L. Uso de fertilizantes orgânicos no cultivo de alface americana (Lactuca sativa L.), Revista Brasileira de Agropecuária Sustentável, v. 6, n. 2, p. 66-74, 2016. https://doi.org/10.21206/rbas.v6i2.308.

Silva, R. F.; Basso, C. J.; Bertollo, G. M.; Corassa, G. M.; Cocco, L. B.; Steffen, R. B. Doses de dejeto líquido de suínos na comunidade da fauna edáfica em sistema de plantio direto e cultivo mínimo. Ciência Rural, v. 44, n. 3, p.418-424, 2014. https://doi. org/10.1590/S0103-84782014000300006.

Souza, R. A.; Hungria, M.; Franchini, J. C.; Chueire, L. M. O.; Barcellos, F. G.; Campo, R. J. Avaliação qualitativa e quantitativa da microbiota do solo e da fixação biológica do nitrogênio pela soja. Pesquisa Agropecuária Brasileira, v. 43, n. 1, p. 71-82, 2008. https://doi. org/10.1590/S0100-204X2008000100010.

Souza, T. A. F.; Rodrigues, A. F.; Marques, L. F. Long-term effects of alternative and conventional fertilization on macroarthropod community composition: a field study witg wheat (Triticum aestivum L.) cultivated on a ferralsol, Organic Agriculture, v. 6, n. 4, p. 323-330. https://doi.org/10.1007/s13165-015-0138-y.

Toniazzo, F.; Becegato, V. A.; Lavnitcki, L.; Rosa, M. M.; Da Ros, C. O.; Becegato, V. A.; Lavnitcki, L.; Henkes, J. A.; Cantoni, F. Avaliação da liberação de $\mathrm{CO}_{2}$ em solo com adição de águas residuárias suinícolas e impactos ambientais e sociais da suinocultura. Revista Gestão \& Sustentabilidade Ambiental, v. 7, n. 1, p. 253-274, 2018. https://doi.org/10.19177/rgsa.v7e12018253-274.

Vance, E.D.; Brookes, P.C.; Jenkinson, D.S. An extraction method for measuring soil microbial biomass. Soil Biology \& Biochemistry, v. 19, n.1, p. 703-707, 1987. https://doi.org/10.1016/00380717(87)90052-6. 